\title{
Genotyping $\mathrm{mdx}$, mdx3cv, and $\mathrm{mdx} 4 \mathrm{cv}$ mice by primer competition PCR
}

\author{
Jin-Hong Shin, MD, PhD, Chady H. Hakim, MS, Keqing Zhang, BS, and Dongsheng Duan, \\ $\mathrm{PhD}{ }^{*}$ \\ Department of Molecular Microbiology and Immunology, School of Medicine
}

\begin{abstract}
Mdx, mdx3cv and mdx4cv mice are among the most commonly used models for Duchenne muscular dystrophy. Their disease is caused by point mutations in the dystrophin gene. Despite wide use of these models, genotyping has not always been straightforward. Current methods require multiple PCRs, post-PCR manipulations and/or special equipment/reagents. Here we report a simple, robust PCR genotyping method based on primer competition. This approach could also be applied in genotyping other point mutation models.
\end{abstract}

\section{Keywords}

Duchenne muscular dystrophy; mdx; mdx3cv; mdx4cv; genotyping; PCR

\section{Introduction}

Duchenne muscular dystrophy (DMD) is the most common lethal childhood muscle disease. It is caused by dystrophin deficiency. Dystrophin-null mice have been widely used to study the molecular pathogenesis of DMD and to develop novel therapies. Mdx, mdx $3 \mathrm{cv}$ and mdx $4 \mathrm{cv}$ mice are among the most commonly used DMD mouse models. Mdx mice carry a spontaneous nonsense mutation in exon 23 of the dystrophin gene. ${ }^{1,2} \mathrm{Mdx} 3 \mathrm{cv}$ and $\mathrm{mdx} 4 \mathrm{cv}$ mice are generated by $\mathrm{N}$-ethylnitrosourea mutagenesis. ${ }^{3} \mathrm{In} \mathrm{mdx} 3 \mathrm{cv}$ mice, a point mutation in intron 65 results in aberrant splicing and disrupted dystrophin expression. ${ }^{4} \mathrm{In} \mathrm{mdx} 4 \mathrm{cv}$ mice, a nonsense point mutation in exon 53 leads to premature translation termination. ${ }^{5}$

In contrast to the severe clinical manifestations seen in human patients, dystrophin-deficient mice display a very mild phenotype. This makes clinical diagnosis extremely challenging if not impossible. A simple, reliable genotyping method would substantially facilitate the use of these models in preclinical studies.

Many methods have been developed for genotyping mdx mice (reviewed in Trebbin et al. ${ }^{6}$ ). Traditional approaches include allele-specific oligonucleotide hybridization, restriction enzyme digestion of the PCR products, snap-back single-strand conformation polymorphism, and the amplification-resistant mutation system (ARMS). ${ }^{7-10}$ The ARMS assay has also been adapted for $\mathrm{mdx} 3 \mathrm{cv}$ and $\mathrm{mdx} 4 \mathrm{cv}$ genotyping. ${ }^{11}$ While quite useful, these methods often involve labor-intensive procedures and require delicate custom refinement. The SNaPshot and high-resolution melt (HRM) assays are new techniques developed in the last couple of years to improve mdx genotyping. ${ }^{6,12}$ These methods increase the specificity

\footnotetext{
*Corresponding Address: Dongsheng Duan Ph.D., Associate Professor, Department of Molecular Microbiology and Immunology, One Hospital Dr. Columbia, MO 65212, Phone: 573-884-9584, Fax: 573-882-4287, duand@missouri.edu.
} 
and sensitivity and allow detection of heterozygous samples. However, they require unconventional instruments such as the HRM PCR machine/software or a capillary electrophoresis system. The SNaPshot method also requires additional post-PCR manipulations. Most recently, a direct sequencing protocol has been developed to allow for an accurate diagnosis. ${ }^{13}$

Here we describe a simple and highly reproducible PCR protocol for mdx, mdx $3 \mathrm{cv}$ and $\mathrm{mdx} 4 \mathrm{cv}$ genotyping. It can be easily implemented in a routine laboratory setting. The method is based on the competition between the wild type allele-specific and mutant allelespecific primers in a single PCR. ${ }^{14}$ The specificity is further enhanced by a two-stage selective amplification protocol.

\section{Materials and Methods}

Animals

All animal experiments were approved by the Animal Care and Use Committee of the University of Missouri and were in accordance with NIH guidelines. C57Bl/6J (wild type BL6), C57B1/10Snj (wild type BL10), C57BL/10ScSn-Dmd ${ }^{\mathrm{mdx}} / \mathrm{J}$ (mdx), B6Ros.Cg-

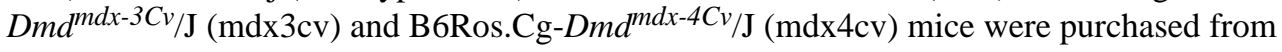
The Jackson Laboratory (Bar Harbor, ME). Heterozygous mice were generated in house by crossing BL10 and mdx, or by crossing BL6 with mdx3 $\mathrm{cv}$ or mdx $4 \mathrm{cv}$.

\section{DNA extraction and PCR conditions}

Tail DNA was extracted using either a high salt precipitation or a brief alkaline lysis protocol. ${ }^{15,16}$ The PCR reaction was carried out in a $20 \mu \mathrm{L}$ volume containing $4 \mu \mathrm{L}$ of $5 \times$ GoTaq Flexi buffer (Promega, Fitchburg, WI), $0.2 \mathrm{mM}$ dNTPs, $2 \mathrm{mM} \mathrm{MgCl} 2,1$ unit GoTaq DNA polymerase (Promega), 150 ng tail DNA, and three primers including a common primer $(0.66 \mu \mathrm{M})$, a wild type allele-specific primer $(0.66 \mu \mathrm{M})$ and a mutant allele-specific primer $(0.66 \mu \mathrm{M})$. The PCR condition was set as (1) an initial denaturation at $95^{\circ} \mathrm{C}$ for 2 min; (2) five cycles of the first stage amplification including $95^{\circ} \mathrm{C}$ denaturation for $20 \mathrm{sec}$, $60^{\circ} \mathrm{C}$ (for $\mathrm{mdx}$ and $\mathrm{mdx} 3 \mathrm{cv}$ ) or $62^{\circ} \mathrm{C}$ (for $\mathrm{mdx} 4 \mathrm{cv}$ ) annealing for $20 \mathrm{sec}$, and $72^{\circ} \mathrm{C}$ extension for $20 \mathrm{sec}$; (3) 23 cycles of the second stage amplification. This is essentially the same as the first stage amplification, except the annealing temperature is raised to $64^{\circ} \mathrm{C}$ (for $\mathrm{mdx}$ and $\mathrm{mdx} 3 \mathrm{cv}$ ) or $66^{\circ} \mathrm{C}$ (for $\mathrm{mdx} 4 \mathrm{cv}$ ); and (4) a final extension at $72^{\circ} \mathrm{C}$ for $1 \mathrm{~min}$. The PCR was performed in an Eppendorf master cycler personal (Hamburg, Germany). The PCR products were resolved in a $3 \%$ agarose gel.

\section{The primers and the size of the expected PCR products}

Three primers were used in mdx genotyping including a common forward primer (DL1577), a wild type allele-specific reverse primer (DL1509) and a mutant allele-specific reverse primer (DL1573). Three primers were used in $\mathrm{mdx} 3 \mathrm{cv}$ genotyping including a common forward primer (DL1578), a wild type allele-specific reverse primer (DL1524) and a mutant allele-specific reverse primer (DL1574). Three primers were used in mdx4cv genotyping including a common reverse primer (DL1579), a wild type allele-specific forward primer (DL1532) and a mutant allele-specific forward primer (DL1575). The primer sequences and the sizes of the expected PCR products are listed in Figure 1.

\section{Results}

The challenge in genotyping a point mutation lies in the difficulties of discriminating the wild type and mutant alleles. In the ARMS method, two separate PCRs are carried out using allele-specific primers that are different only at the last nucleotide. This often leads to non- 
specific amplification of the wrong allele, especially when the reaction condition is suboptimal. $6,7,11,12$ Occasionally, a unique restriction enzyme site may exist in either the wild type or mutant allele PCR products. This enables the diagnosis by the digestion pattern. 10,17

To distinguish the wild type and mutant alleles in a single PCR reaction, we introduced several modifications (Fig. 1B). First, we added a long non-specific tail to the wild type allele-specific primer. This resulted in a larger band from the wild type allele (Fig. 1). Second, we mixed the wild type and mutant allele-specific primers together in the reaction. Competition between these two primers reduces erroneous binding and extension. ${ }^{14}$ Third, we designed a two-stage PCR reaction. The first stage included five cycles at a relatively low annealing temperature. During this stage, the genomic DNA was used as the template. Because of the competition between the wild type and mutant specific primers, the PCR products are enriched with the correct amplicons. The bulk of the PCR reaction ( 23 cycles) was performed at a more stringent condition at an annealing temperature $4^{\circ} \mathrm{C}$ higher. Since the amplicons of the first stage PCR carried DNA sequences perfectly matched with the primers, they were preferentially amplified. Untoward annealing (to the genomic DNA template) and amplification (of the genomic DNA) from the mismatched primer were minimized. To facilitate the second stage PCR, we have included a short GC-rich tail to the common and the mutant allele-specific primers.

We applied this strategy to $\mathrm{mdx}, \mathrm{mdx} 3 \mathrm{cv}$ and $\mathrm{mdx} 4 \mathrm{cv}$ genotyping (Fig. 1C). Consistent results were obtained for homozygous (female), heterozygous (female) and hemizygous (male) mice irrespective of the strain and age (Fig. 1C). Of 288 genotypings performed for mdx mice, a correct diagnosis was reached on $96.4 \%$ occasions. The success rate for mdx $3 \mathrm{cv}$ (77 reactions) and $\mathrm{mdx} 4 \mathrm{cv}$ (99 reactions) reached $94.8 \%$ and $99 \%$, respectively. The occasional failures were all correctly diagnosed after re-extracting the genomic DNA and redoing PCR.

\section{Discussion}

Point mutation dystrophin-null mice are powerful tools in DMD research. They have been intensively used to study dystrophin domain function, identify genetic modifier and test new therapy. The genotyping protocol described here will be very useful, especially when complicated crossings are involved. This strategy may also help to genotype point mutations in other disease models.

\section{Acknowledgments}

Grant support: This work was supported by grants from the National Institutes of Health (AR-49419, DD) and the Muscular Dystrophy Association (DD).

\section{Abbreviations}

$\begin{array}{ll}\text { ARMS } & \text { amplification-resistant mutation system } \\ \text { DMD } & \text { Duchenne muscular dystrophy } \\ \text { HMR } & \text { high-resolution melt } \\ \text { PCR } & \text { polymerase chain reaction }\end{array}$




\section{References}

1. Bulfield G, Siller WG, Wight PA, Moore KJ. X chromosome-linked muscular dystrophy (mdx) in the mouse. Proc Natl Acad Sci U S A 1984;81(4):1189-1192. [PubMed: 6583703]

2. Sicinski P, Geng Y, Ryder-Cook AS, Barnard EA, Darlison MG, Barnard PJ. The molecular basis of muscular dystrophy in the mdx mouse: a point mutation. Science 1989;244(4912):1578-1580. [PubMed: 2662404]

3. Chapman VM, Miller DR, Armstrong D, Caskey CT. Recovery of induced mutations for X chromosome-linked muscular dystrophy in mice. Proc Natl Acad Sci U S A 1989;86(4):1292-1296. [PubMed: 2919177]

4. Cox GA, Phelps SF, Chapman VM, Chamberlain JS. New mdx mutation disrupts expression of muscle and nonmuscle isoforms of dystrophin. Nat Genet 1993;4(1):87-93. [PubMed: 8099842]

5. Im WB, Phelps SF, Copen EH, Adams EG, Slightom JL, Chamberlain JS. Differential expression of dystrophin isoforms in strains of mdx mice with different mutations. Hum Mol Genet 1996;5(8): 1149-1153. [PubMed: 8842734]

6. Trebbin AL, Hoey AJ. A novel and simple method for genotyping the mdx mouse using highresolution melt polymerase chain reaction. Muscle Nerve 2009;39(5):603-608. [PubMed: 19347923]

7. Amalfitano A, Chamberlain JS. The mdx-amplification-resistant mutation system assay, a simple and rapid polymerase chain reaction-based detection of the mdx allele. Muscle Nerve 1996;19(12): 1549-1553. [PubMed: 8941268]

8. Chamberlain JS, Farwell NJ, Chamberlain JR, Cox GA, Caskey CT. PCR analysis of dystrophin gene mutation and expression. J Cell Biochem 1991;46(3):255-259. [PubMed: 1774226]

9. Wilton SD, Honeyman K, Fletcher S, Laing NG. Snapback SSCP analysis: engineered conformation changes for the rapid typing of known mutations. Hum Mutat 1998;11(3):252-258. [PubMed: 9521428]

10. Shrager JB, Naji A, Kelly AM, Stedman HH. A PCR-based assay for the wild-type dystrophin gene transferred into the mdx mouse. Muscle Nerve 1992;15(10):1133-1137. [PubMed: 1357549]

11. Pearson-White SH. DMD $(m d x 3 C v)$ and $\mathrm{DMD}(\mathrm{mdx} 4 \mathrm{Cv})$ dystrophin mutations in mice: rapid polymerase chain reaction genotyping. Neuromuscul Disord 2002;12(4):366-370. [PubMed: 12062254]

12. Budowle SA, Gonzalez S, Budowle B, Eisenberg AJ, Grange RW. A novel SNaPshot assay to detect the mdx mutation. Muscle Nerve 2008;37(6):731-735. [PubMed: 18506711]

13. Banks GB, Combs AC, Chamberlain JS. Sequencing protocols to genotype $\mathrm{mdx}, \mathrm{mdx}(4 \mathrm{cv})$, and $\operatorname{mdx}(5 \mathrm{cv})$ mice. Muscle Nerve. 2010 In-press.

14. Fauser S, Wissinger B. Simultaneous detection of multiple point mutations using fluorescencecoupled competitive primer extension. Biotechniques 1997;22(5):964-968. [PubMed: 9149883]

15. Truett GE, Heeger P, Mynatt RL, Truett AA, Walker JA, Warman ML. Preparation of PCR-quality mouse genomic DNA with hot sodium hydroxide and tris (HotSHOT). Biotechniques 2000;29(1): 52, 54. [PubMed: 10907076]

16. Duan D, Yue Y, Zhou W, Labed B, Ritche TC, Grosschedl R, Engelhardt JF. Submucosal Gland Development in the Airway is Controlled by Lymphoid Enhancer Binding Factor-1 (Lef-1). Development 1999;126(20):4441-4453. [PubMed: 10498680]

17. Bartlett RJ, Winand NJ, Secore SL, Singer JT, Fletcher S, Wilton S, Bogan DJ, Metcalf-Bogan JR, Bartlett WT, Howell JM, Cooper BJ, Kornegay JN. Mutation segregation and rapid carrier detection of X-linked muscular dystrophy in dogs. Am J Vet Res 1996;57(5):650-654. [PubMed: 8723876] 


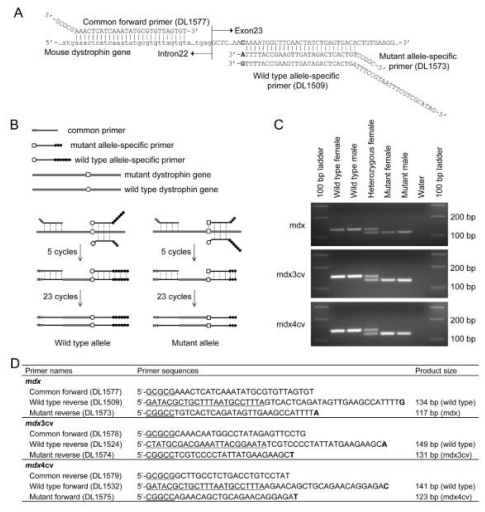

Figure 1. Primer competition PCR for $\mathrm{mdx}$, $\mathrm{mdx} 3 \mathrm{cv}$ and $\mathrm{mdx} 4 \mathrm{cv}$ genotyping (A) Schematic outline of the primers used for mdx genotyping. The common forward primer is located at intron 22. The allele-specific reverse primers are located at exon 23. Small letter, intron sequence; bolded letter, nucleotide at the position of mutation. In the wild type mouse dystrophin gene, it is " $C$ ", while it should be "T" in the mutated gene of mdx mice (not shown). Synthetic tails of the primers do not match with the dystrophin gene sequence. (B) Schematic outline of the primer competition PCR method. The first five cycles are performed at a relatively low annealing temperature aiming to amplify the mouse genomic DNA. The allele-specific primers compete with each other for the binding and extension on the genomic DNA templates. The following 23 cycles are carried out at an annealing temperature $4^{\circ} \mathrm{C}$ higher. This allows preferential amplification of the products from the first stage PCR. Open circle (O), the wild type nucleotide at the position of mutation; open box $(\square)$, the mutated nucleotide at the position of mutation; open triangle $(\triangleright)$, the synthetic tail added to the common forward primer; filled circle $(\bullet)$, the synthetic tail added to the wild type allele-specific primer; filled diamond $(>)$, the synthetic tail added to the mutant allelespecific primer. (C) Representative genotyping results from each indicated strain. Water, negative control without the tail DNA template. (D) PCR primers and the expected PCR band sizes for $\mathrm{mdx}, \mathrm{mdx} 3 \mathrm{cv}$ and $\mathrm{mdx} 4 \mathrm{cv}$ genotyping. The bolded letters represent allelespecific nucleotides at the position of the mutation. The underlined nucleotides are not present in the dystrophin gene. In the case of common and mutant allele-specific primers, they are GC-rich nucleotides. They increase the melting temperature to meet the need of the second stage PCR. In the case of wild type allele-specific primers, these nucleotides are chosen arbitrarily. They allow the wild type allele to yield a larger PCR product. 